\title{
Identifikasi Kelayakan Kawasan Pecinan Lasem sebagai Kawasan Konservasi
}

\author{
Sintia Dewi Wulanningrum \\ Jurusan Arsitektur, Fakultas Teknik, Universitas Tarumanagara Jakarta \\ Email: sintiadewe@gmail.com/sintiaw@ft.untar.ac.id
}

\begin{abstract}
ABSTRAK
Kawasan Pecinan Lasem merupakan kawasan cagar budaya yang memiliki keunikan dilihat dari sejarah, budaya dan arsitekturnya. Keistimewaan di kawasan Pecinan Lasem antara lain: kawasan yang dihuni oleh orang-orang Cina dengan budaya Cina yang kental, di kawasan tersebut terdapat pemukiman atau rumah tinggal dan rumah persembahan (Klenteng). Dilihat dari nilai sejarah Lasem yang merupakan Pecinan tertua di Indonesia, serta banyaknya kelenteng yang digunakan sebagai pusat religi masyarakat Pecinan Lasem. Selain itu, peninggalan bersejarah di kawasan Pecinan menunjukkan bahwa pada jaman dahulu Lasem adalah salah satu kota pelabuhan yang besar, dimana pelabuhan Lasem merupakan pintu gerbang masuknya pendatang asing terutama orang-orang Cina, oleh sebab itu kawasan Pecinan Lasem dikenal sebagai "Petit Chinois". Akan tetapi, seiring dengan perkembangan yang terjadi saat ini, pembangunan yang mengarah pada hal yang lebih bersifat modern telah mengakibatkan terjadinya perubahan-perubahan. Salah satu perubahan yang nampak adalah adanya perubahan terhadap zoning dan tata guna lahan, serta perubahan bentuk fisik bangunan.Masalah peningkatan jumlah penduduk yang disertai masalah dalam bidang transportasi juga telah terjadi pada struktur eksisting di Rembang yang juga mempengaruhi Kawasan Pecinan Lasem. Penelitian bertujuan untuk mengidentifikasi kelayakan kawasan Pecinan sebagai kawasan konservasi serta penentuan zonasi berdasarkan kelayakan kawasan konservasi. Metode penelitian adalah deskriptif kualitatif untuk mengidentifikasi kelayakan kawasan berdasarkan zona prioritas sebagai kawasan konservasi yang mengacu pada evaluasi kelayakan konservasi. Hasil penelitian yaitu terdapat tiga Zona Kawasan yang memiliki prioritas untuk dikembangkan. Berdasarkan hasil penilaian kelayakan kawasan konservasi menunjukkan bahwa Kawasan Soditan dan kawasan Karang Turi merupakan kawasan yang memiliki potensi untuk dikembangkan.
\end{abstract}

Kata kunci: pecinan lasem, identifikasi kelayakan, konservasi, zona prioritas

\section{PENDAHULUAN}

Kecamatan Lasem terletak di wilayah Kabupaten Rembang dengan jarak $15 \mathrm{~km}$ dari kota Rembang ke arah timur, mempunyai karakteristik yang berbeda karena terdapat keunikankeunikan yang jarang ditemui di kecamatan-kecamatan lain terutama di sepanjang pantai utara Jawa. Salah satu diantaranya adalah adanya Kawasan Pecinan Lasem. Pecinan adalah wilayah atau kawasan yang dihuni oleh orang-orang Cina dengan budaya Cina yang kental, dimana di kawasan tersebut terdapat pemukiman atau rumah tinggal dan rumah persembahan (Klenteng). Kawasan Pecinan merupakan kawasan dengan domain ekonomi kota, dimana kawasan ini biasanya berfungsi sebagai sentra ekonomi dan hunian (Adhisakti, 2013). Selain itu, kawasan Pecinan adalah kawasan yang merujuk pada suatu bagian kota yang dari segi penduduk, bentuk hunian, tatanan sosial serta suasana lingkungannya memiliki ciri khas karena pertumbuhan bagian kota tersebut berakar secara historis dari masyarakat Cina (Gracea, Diana dan Dewi, S. Rima, 2014).

Kawasan Pecinan Lasem merupakan salah satu daerah berpotensi yang dapat dikembangkan sebagai daerah wisata sejarah Arsitektur pecinan di Lasem mempunyai ciri spesifik dimana terdapat sebuah pintu gerbang besar (regol). Meskipun masih ada variasi-variasi lain tetapi tetap terlihat bahwa bangunan itu mempunyai prototype dari arsitektur Cina yaitu terdapat sebuah halaman yang luas dapat ditemui sewaktu membuka pintu gerbang tersebut. Peninggalan arsitektur seperti itu sudah jarang ditemui di pulau Jawa, khususnya Jawa Tengah. Kelebihan lain yang ditemukan di Kawasan Pecinan Lasem adalah adanya lahan luas yang dibatasi dengan benteng di sekelilingnya. Secara lokasi bangunan-bangunan tua ini terletak di Desa Karangturi, Desa Babagan, Desa Soditan dan Desa Sumber Girang. Bangunan-bangunan kuno di Kawasan Pecinan Lasem tersebut merupakan identitas dan kekhasan kawasan serta menjadi bukti sejarah 
yang perlu dilindungi, selain itu juga merupakan prasasti pertautan budaya Tionghoa dan Jawa serta akulturasi Islam dan Tionghoa yang berlangsung harmonis sehingga perlu untuk dilestarikan. Karya arsitektur Pecinan tersebut merupakan salah satu peninggalan bersejarah yang ada di Pulau Jawa. Peninggalan bersejarah tersebut menunjukkan bahwa pada jaman dahulu Lasem adalah salah satu kota pelabuhan yang besar, dimana pelabuhan Lasem merupakan pintu gerbang masuknya pendatang asing terutama orang-orang Cina, sehingga oleh orang Prancis dulu dijuluki "Petit Chinois" yg artinya China kecil.

Keunikan ini juga menarik peneliti untuk melakukan kajian di Kawasan Pecinan Lasem. Fajar (2005) melakukan studi mengenai, "Studi Identifikasi dan Penentuan Kawasan Pecinan Lasem”. Temuan dari studi ini terkait dengan parameter berupa arsitektur bangunan yaitu arsitektur bangunan rumah tinggal dan tempat ibadah merupakan arsitektur perpaduan antara gaya arsitektur Tionghoa dengan arsitektur colonial. Hasanah (2014) meneliti tentang "Perayaan Imlek Etnis Tionghoa": Menakar Implikasi Psiko-Sosiologis Perayaan Imlek bagi Komunitas Muslim di Lasem Rembang. Kajian ini berupaya mendeskripsikan implikasi psikologis perayaan imlek etnis Tionghua bagi komunitas Muslim di Lasem Rembang. Atabik (2016) meneliti mengenai "Harmonisasi Kerukunan Antar Etnis Dan Penganut Agama Di Lasem". Dari sini terlihat adanya harmonisasi antar entis dan umat beragama di Lasem sejak zaman jauh sebelum Indonesia merdeka hingga sekarang ini. Darmawan meneliti tentang "Yin yang, chi dan wu xing pada arsitektur kelenteng", studi kasus kelenteng sebelum abad 19 di Lasem, Rembang dan Semarang. Dari penelitian terlihat adanya harmonisasi antar entis dan umat beragama di Lasem sejak zaman jauh sebelum Indonesia merdeka hingga sekarang ini. Selain itu, dilakukan penelitian mengenai "Pemahaman mengenai relasi konsep fungsi, bentuk dan makna arsitektur rumah tinggal masyarakat kota pesisir utara di kawasan Jawa Timur", dengan kasus studi rumah tinggal di Kampung Karangturi dan Kampung Sumber Girang, Lasem . Bentuk arsitektur lokal di kawasan Pesisir Utara Jawa Timur merupakan arsitektur lokal yang sangat dipengaruhi oleh nilai-nilai etnis budaya Cina (Fauzy, Antariksa 2011).

Dari kondisi bangunan bersejarah yang terdapat di Kawasan Pecinan Lasem, maka perlu dilakukan konservasi kawasan sebagai bentuk pengelolaan bangunan-bangunan tua di Kota Lasem. Konservasi Kawasan Pecinan Lasem perlu dilakukan sebagai salah satu upaya pelestarian nilai sejarah suatu kawasan. Hal tersebut dilakukan dengan harapan nilai-nilai kultur akan terpelihara dengan baik yang akan bermanfaat bagi masa sekarang dan masa depan, sehingga ketika melewati Kawasan Pecinan di Lasem akan melihat karakter arsitektural kawasan dari ragam, etnik budaya Pecinan dan karakter place kawasan. Dengan adanya UU No. 11 tahun 2010 tentang cagar budaya yang mengarah pada akan arti penting dari melestarikan budaya dan sejarah, menyatakan bahwa tujuan dari pelestarian adalah: (a) melestarikan warisan budaya bangsa dan warisan umat manusia, (b) meningkatkan harkat dan martabat bangsa melalui Cagar Budaya, (c) memperkuat kepribadian bangsa, (d) meningkatkan kesejahteraan rakyat; dan (e) mempromosikan warisan budaya bangsa kepada masyarakat internasional. Konservasi ini tidak hanya bertujuan untuk mengembalikan suatu kesan masa lalu karena konservasi hanya melestarikan apa yang ada sekarang dan mengarahkan perkembangan di masa depan (Catanese, Anthony J dan James C. Snyder (1989). Berdasarkan sejarah perkembangan, aset dan potensi yang dimiliki oleh Kawasan Pecinan Lasem memang layak dikategorikan sebagai kawasan konservasi. Hal ini diperkuat oleh Undang-Undang (UU) Nomor 5 Tahun 1992 tentang Benda Cagar Budaya. Pada Pasal 1 (1) disebutkan, benda cagar budaya adalah benda buatan manusia, bergerak atau tidak bergerak yang berupa kesatuan atau kelompok, atau bagian-bagiannya atau sisa-sisanya, yang berumur sekurang-kurangnya 50 (lima puluh) tahun, atau mewakili masa gaya yang khas dan mewakili masa gaya sekurang-kurangnya 50 (lima puluh) tahun, serta dianggap 
mempunyai nilai penting bagi sejarah, ilmu pengetahuan, dan kebudayaan. Selain itu, untuk mengetahui tekstur fisik sebuah kota dapat dilakukan melalui pendekatan morfologi kota, dengan menggunakan analisis figure ground, linkage theory dan theory of place (Zahnd, Markus, 1999).

\section{Rumusan Masalah}

Sejak tahun 1986, Pemerintah Kabupaten Rembang juga telah menetapkan bangunan-bangunan tua di Lasem sebagai bangunan cagar budaya yang harus di lindungi keberadaannya. Akan tetapi, seiring dengan perkembangan yang terjadi saat ini, pembangunan mengarah pada hal yang lebih bersifat modern telah mengakibatkan terjadinya perubahan-perubahan. Salah satu perubahan yang nampak adalah adanya perubahan terhadap zoning dan tata guna lahan, serta perubahan bentuk fisik bangunan. Untuk keberadaan di masa mendatang, kelestarian bangunan kuno di Kawasan Pecinan Lasem tersebut perlu diselamatkan. Dengan perkembangan pembangunan karena tuntutan modernisasi, pergeseran sikap dan mentalitas para pemilik bangunan kuno untuk memodernisasi Kawasan Pecinan Lasem dapat mengancam kelestarian bangunan kuno yang ada. Disamping itu, permasalahan lainnya seperti kurangnya pengelolaan terhadap perawatan bangunan-bangunan Pecinan yang sudah rapuh.

Rumusan masalah adalah bagaimana identifikasi kelayakan kawasan Pecinan Lasem sebagai kawasan konservasi untuk menjaga kelestarian Kawasan Pecinan Lasem di masa datang serta bagaimanakah pengelompokkan zona-zona prioritas di Pecinan Lasem yang memiliki potensi prioritas untuk dikembangkan.

Berdasarkan latar belakang dan rumusan masalah di atas, tujuan penulisan ini adalah untuk mengidentifikasi kelayakan kawasan Pecinan sebagai kawasan konservasi serta penentuan zonasi berdasarkan kelayakan kawasan konservasi dan memberikan masukan, rekomendasi dalam melakukan pelestarian kota kawasan kota lama (Kawasan Pecinan Lasem) dengan memanfaatkan ruang kota secara optimal melalui pembagian zonasi berdasarkan evaluasi kajian kelayakan.

\section{METODE PENELITIAN}

Metode penelitian dengan cara deskriptif kualitatif untuk mengidentifikasi kelayakan di kawasan Pecinan Lasem . Teknik mengumpulkan data primer melalui observasi langsung dan sekunder melalui studi literatur (jurnal, buku serta peraturan mengenai konservasi kawasan). Setelah data terkumpul, kemudian data dianalisa dengan menggunakan teknik scoring untuk mengetahui zona -zona mana yang memiliki potensi kelayakan berdasarkan Kriteria Evaluasi Kelayakan Kawasan Konservasi (Catanese \& Anthony J. (1989) dan Budiharjo, Eko (1985)).

\section{Lokasi Pengambilan Data dan Alat yang digunakan}

Penelitian dilakukan di Kawasan Pecinan Lasem, yang terdiri dari empat desa yaitu : . Kawasan Soditan, Karang Turi, Kawasan Babagan, dan Kawasan Sumber Girang . Pemetaan kawasan dengan menggunakan autocad.

\section{Teknik Pengumpulan Data}

Pengumpulan data yang dilakukan pada penelitian ini yaitu data primer dan data sekunder. Untuk data primer didapat dengan cara observasi langsung di lapangan, dokumentasi dengan kamera digital. Sedangkan data sekunder melalui studi literatur (jurnal, buku serta peraturan mengenai konservasi kawasan). Data yang dikumpulkan antara lain gambaran umum kawasan Pecinan Lasem, potensi kawasan serta data keruangan (morfologi kota). Setelah data terkumpul, 
kemudian data dianalisa dan khusus untuk identifikasi kelayakan kawasan konservasi dianalisa dengan menggunakan teknik scoring untuk mengetahui zona -zona mana yang memiliki potensi kelayakan berdasarkan Kriteria Evaluasi Kelayakan Kawasan Konservasi antara lain : estetika, keluarbiasaan, peranan sejarah, kelangkaan, karakter bangunan dan memperkuat citra kawasan . Menurut Catanese \& Anthony J. (1989) dan Budiharjo, Eko (1985), ada beberapa kriteria evaluasi kelayakan kawasan konservasi, seperti yang dijelaskan dalam tabel berikut ini.

Tabel 1. Kriteria evaluasi kelayakan kawasan konservasi

\begin{tabular}{|c|c|c|c|}
\hline No. & KRITERIA & DEFINISI & TOLAK UKUR \\
\hline 1. & Estetika & $\begin{array}{l}\text { Terkait dengan perubahan estetis dan } \\
\text { arsitektonis bangunan (gaya bangunan, } \\
\text { atap, fasade/selubung bangunan, } \\
\text { ornamen/elemen, dan bahan) }\end{array}$ & $\begin{array}{l}\text { Perubahan gaya bangunan, atap, } \\
\text { fasade/selubung bangunan, } \\
\text { ornamen/elemen serta struktur dan } \\
\text { bahan }\end{array}$ \\
\hline 2. & Keluarbiasaan & $\begin{array}{l}\text { Memiliki ciri khas yang dapat diwakili } \\
\text { oleh faktor usia, ukuran, bentuk } \\
\text { bangunan, dan lain sebagainya }\end{array}$ & $\begin{array}{l}\text { Peran kehadirannya dapat } \\
\text { meningkatkan kualitas serta citra dan } \\
\text { karakter bangunan }\end{array}$ \\
\hline 3. & $\begin{array}{l}\text { Peranan } \\
\text { sejarah }\end{array}$ & $\begin{array}{l}\text { Berkaitan dengan sejarah baik kawasan } \\
\text { maupun bangunan itu sendiri }\end{array}$ & $\begin{array}{l}\text { Berkaitan dengan peristiwa } \\
\text { bersejarah sebagai hubungan } \\
\text { simbolis peristiwa dahulu dan } \\
\text { sekarang }\end{array}$ \\
\hline 4. & Kelangkaan & $\begin{array}{l}\text { Bentuk, gaya serta elemen-elemen } \\
\text { bangunan dan penggunaan ornamen yang } \\
\text { berbeda dan tidak terdapat pada } \\
\text { bangunan lain }\end{array}$ & $\begin{array}{l}\text { Merupakan bangunan yang langka } \\
\text { dan tidak terdapat di daerah lain }\end{array}$ \\
\hline 5. & $\begin{array}{l}\text { Karakter } \\
\text { Bangunan }\end{array}$ & $\begin{array}{l}\text { Memiliki peran yang penting dalam } \\
\text { pembentukan karakter bangunan }\end{array}$ & $\begin{array}{l}\text { Memiliki ciri khas seperti usia } \\
\text { bangunan, ukuran/luas bangunan, } \\
\text { bentuk bangunan, dan sebagainya }\end{array}$ \\
\hline 6. & $\begin{array}{l}\text { Memperkuat } \\
\text { citra kawasan }\end{array}$ & $\begin{array}{l}\text { Memiliki peran yang penting dalam } \\
\text { pembentukan karakter kawasan }\end{array}$ & $\begin{array}{l}\text { Peran kehadirannya dapat sesuai } \\
\text { dengan fungsi kawasan dan } \\
\text { meningkatkan kualitas serta citra dan } \\
\text { karakter kawasan }\end{array}$ \\
\hline
\end{tabular}

Setelah diketahui kriteria evaluasi kelayakan tersebut, kemudian dilakukan penilaian konservasi dengan metode evaluative yaitu:

- Masing-masing kriteria tersebut dibagi menjadi tiga tingkatan, yaitu tinggi, sedang dan rendah. Yang sesuai dengan kondisi bangunan ditinjau dari makna kultural elemen-elemen bangunan. Setiap tingkatan mempunyai bobot nilai tertentu.

- Bobot penilaian ini juga dapat digunakan pada bobot nilai yang berbeda juga. Penelitian ini menggunakan scoring dengan tiap kriteria dibagi menjadi tiga tingkatan mulai rendah, sedang dan tinggi, yaitu 1,2 dan 3 .

\section{HASIL DAN PEMBAHASAN}

\section{Kelayakan Kawasan Pecinan Lasem sebagai Kawasan Konservasi}

Kawasan Pecinan Lasem dengan bangunan-bangunan tua cina sebagai bangunan cagar budaya yang harus di lindungi keberadaannya, mempunyai beberapa kriteria kelayakan konservasi yang dapat dijelaskan sebagai berikut:

\section{Kelangkaan}

Arsitektur pecinan di Lasem mempunyai ciri spesifik yaitu bentuk denah menggunakan prinsip simetri dan seimbang baik dalam satu kompleks. Denahnya berbentuk persegi panjang dan terdapat halaman/courtyard yang mengelilingi dengan bentuk persegi pula. Terdapat sebuah pintu gerbang besar (regol) yang mengelilingi bangunan rumah utama sehingga terlihat seperti benteng. Pintu gerbang tersebut merupakan "point of interest" dari 
ruang luar ke ruang dalam. Meskipun masih ada variasi-variasi lain tetapi tetap terlihat bahwa bangunan itu mempunyai prototype dari arsitektur Cina. Peninggalan arsitektur Cina seperti pintu gerbang besar (regol) pada kawasan permukimannya sudah jarang ditemui di pulau Jawa, khususnya Jawa Tengah.

2. Peranan Sejarah

Dilihat dari sejarahnya, Kawasan Pecinan Lasem merupakan pecinan tertua di Indonesia. Kawasan Pecinan Lasem mempunyai nilai lebih dibandingkan kawasan pecinan lain yang ada di Jawa, khususnya Jawa Tengah, karena karya arsitektur pecinan dengan langgam khas seperti atap pelana kuda dan ornamen tou-kung pada bangunan istana, kuil atau rumah tinggal menjadi ciri khas dari bangunan cina. Disamping itu, banyaknya kelenteng yang digunakan sebagai pusat religi masyarakat pecinan Lasem, dimana konon Lasem merupakan puncak prosesi dari seluruh kelenteng yang ada di jalur pantura maupun Jawa, sehingga Lasem mendapatkan julukan sebagai Tiongkoknya Jawa. Peninggalan bersejarah tersebut juga menunjukkan bahwa pada jaman dahulu Lasem adalah salah satu kota pelabuhan yang besar, dimana pelabuhan Lasem merupakan pintu gerbang masuknya pendatang asing terutama orang-orang Cina.

\section{Keistimewaan}

Pengaruh kebudayaan Cina terasa mendominasi pada banyak segi kehidupan Kota Lasem. Banyak sekali peninggalan bangunan-bangunan tuanya yang sudah berusia ratusan tahun, dimana kebanyakan bangunan bernuansa arsitektur khas Cina meski ada juga yang bernuansa eropa klasik. Tidak salah jika Kota Lasem pernah dijuluki "The Little Beijing Old Town" oleh seorang peneliti eropa zaman kolonial. Oleh orang Prancis dulu dijuluki "Petit Chinois" yg artinya China kecil.

\section{Estetika}

Di Lasem kelenteng merupakan 'tengaran' (landmark) bagi kotanya. Pada perayaan hari raya Cina (misalnya Imlek atau Cap Go Me), maka peran jalan yang dipergunakan sebagai ruang publik pada waktu perayaan keagamaan (hari besar orang China), akan terlihat jelas. Jalan sebagai tempat prosesi perayaan tersebut terjadi sebagai akibat dari perletakan ketiga kelenteng yang ada di Lasem. Berdirinya kelenteng baru tersebut sebagai akibat dari berkembangnya permukiman Cina di sana.

\section{Kejamakan}

Berkembangnya permukiman Cina di Lasem pada tahun 1600an dan berdirinya Kelenteng Poo An Bio pertama kali di wilayah Karangturi yang merupakan salah satu simbul kelenteng tertua di Lasem, menunjukkan bahwa pada jaman Kerajaan Lasem banyak pedagang Cina yang berinteraksi dengan penduduk lokal pada akhirnya membentuk suatu permukiman di sekitar dermaga tepi Kali Lasem dengan pusatnya kelenteng $\mathrm{Cu}$ An Kiong.

6. Memperkuat kawasan sekitar

Bangunan-bangunan kuno di Kawasan Pecinan Lasem tersebut merupakan identitas dan kekhasan kawasan dan menjadi bukti sejarah yang perlu dilindungi, selain itu juga merupakan prasasti pertautan budaya Tionghoa dan Jawa serta akulturasi Islam dan Tionghoa yang berlangsung harmonis sehingga perlu untuk dilestarikan.

Perkembangan Kawasan Pecinan Lasem menjadi kawasan wisata budaya dan sejarah harus melibatkan unsur konservasi yang harus melekat pada daerah Pecinan tersebut. Kawasan Permukiman Pecinan Lasem pada dasarnya menjadi kawasan cagar budaya dikatakan layak untuk dilestarikan dengan melihat dari beberapa kriteria-kriteria antara lain: kelangkaan, peranan sejarah, keistimewaan, estetika, kejamakan dan dapat memperkuat kawasan sekitar. 


\section{Analisis Keruangan Kawasan Pecinan Lasem (figure ground theory, linkage theory dan theory of place)}

Berdasarkan figure ground theory yang ada, Kawasan Pecinan Lasem mempunyai void (ruang terbuka) yang relatif lebih kecil daripada struktur bangunan atau solid (ruang terbangun) yang ada. Solid terdiri dari perumahan pecinan berlantai $1-2$, ruko dan klenteng yang memenuhi kawasan Pecinan, dimana dari elemen solid tersebut dapat menceritakan perkembangan permukiman cina dengan rumah cina yang mempunyai tembok-tembok tinggi membentuk suatu benteng. Sedangkan void merupakan ruang terbuka yang belum terisi sebagai public domain antara lain pedestrian (koridor jalan) yang terbentuk dari barisan bangunan dan alur sungai yang berada di kawasan Lasem. Dari aliran sungai tersebut menunjukkan bahwa kedatangan orang cina melalui transportasi air Sungai Lasem tersebut. Kecenderungan yang ada menunjukkan bahwa Kawasan Pecinan Lasem berbentuk horizontal. Dari tipe pola kepadatan dan kekosongan yang ada di Kawasan Pecinan Lasem mempunyai pola grid.

Tipe yang paling cocok diterapkan dalam Kawasan Pecinan Lasem adalah teori group. Hal ini disebabkan karena bentuk group merupakan hasil akumulasi tambahan dari elemen-elemen dalam ruang sepanjang armature dan juga tipe khusus dari kota bersejarah. Linkage dari Kawasan Pecinan Lasem ditunjukkan dengan adanya pusat-pusat kegiatan yang menjadi penghubung kawasan seperti kelenteng, permukiman dan pelabuhan sehingga mengetahui keterhubungan antara kawasan yang satu dengan kawasan yang lain di Kawasan Pecinan Lasem. Bila teori place ini dipakai untuk melihat Kawasan Pecinan Lasem, maka kultur dan budaya yang terlihat pada kawasan ini adalah kultur atau budaya Cina, dimana budaya Cina mulai datang sejak Lasem menjadi salah satu pusat penampungan dan perlawanan terhadap pemerintah Belanda pada akhir peristiwa pembunuhan orang Tionghoa secara besar-besar sehingga membuat lingkungan perumahannya menjadi sangat tertutup. Lasem menyimpan cerita tentang opium atau candu, di mana jejaknya bisa ditemukan di Omah Lawang Amba, milik Kapten Liem. Dulu Lasem merupakan salah satu pusat penyelundupan candu di Jawa. Bangunanbangunannya mempunyai tembok yang tinggi untuk upaya perlindungan terhadap aktivitas penyelundupan candu tersebut. Lasem kota tua yang terkenal karena banyaknya orang Tionghoa disana, mempunyai lingkungan perumahan yang khas dengan bernuansa arsitektur China. Oleh karena itu sense of place yang ditimbulkan dari Kawasan Pecinan Lasem yaitu budaya cina yang kental di dalamnya.

\section{Penetapan Zonasi Konservasi Kawasan Pecinan Lasem}

Kawasan Pecinan Lasem terletak di empat desa yaitu Desa Karangturi, Desa Babagan, Desa Soditan dan Desa Sumber Girang. Menurut potensinya, ada beberapa potensi dari masingmasing kawasan pecinan di desa tersebut sehingga kawasan permukiman pecinan layak menjadi kawasan konservasi, yaitu di antaranya:

1) Kawasan Karangturi

Kawasan Karangturi dapat dibedakan menjadi dua yaitu: daerah dekat jalan dan daerah pedalaman. Daerah dekat jalan memiliki potensi untuk dikembangkan menjadi area perdagangan dan jasa karena dilalui oleh jalur transportasi Semarang-Surabaya. Sebagian besar daerah tersebut digunakan untuk bangunan ruko dan rumah tinggal. Untuk daerah permukimannya, potensial untuk dikembangkan sebagai daerah wisata sejarah agar para wisatawan dapat menikmati kawasan pecinan yang kaya akan keindahan arsitekturnya dan dapat bernostalgia akan sejarah kawasan pecinan yang berkembang di dalamnya. Terdapat Kelenteng Poo An Bio yang menjadi pusat ibadah bagi masyarakat Cina yang tinggal di sekitar kawasan permukimannya.

2) Kawasan Babagan 
Kawasan Babagan memiliki daerah permukiman pecinan yang lebih sedikit daripada daerah Karangturi. Lokasinya dekat dengan Sungai Babagan, terminal bus dan stasiun kereta api. Terdapat Kelenteng Gie Yong Bio yang menjadi landmark di kawasan permukiman pecinan Babagan.

3) Kawasan Soditan

Kelenteng $\mathrm{Cu}$ An Kiong berada di kawasan Soditan dan menjadi nilai place dari Kawasan Pecinan. Kawasan permukiman pecinannya pun masih asli dan dapat menjadi magnet untuk menarik wisatawan untuk datang. Oleh karena itu, kawasan Soditan sangat potensial untuk dikembangkan sebagai daerah wisata sejarah. Adapun Sungai Babagan yang melewati daerah tersebut potensial untuk dikembangkan menjadi wisata perairan untuk mengetahui perkembangan pecinan di lokasi tersebut.

4) Kawasan Sumber Girang

Kawasan pecinan yang terdapat di daerah ini sangat sedikit, karena lokasinya dekat dengan pasar yang cocok dikembangkan sebagai area perdagangan dan jasa sekitar.

Tabel 2. Evaluasi kelayakan kawasan konservasi di kawasan pecinan lasem

\begin{tabular}{llcccc}
\hline \multirow{2}{*}{ No. } & Kriteria & $\begin{array}{c}\text { Kawasan } \\
\text { Karang Turi }\end{array}$ & $\begin{array}{c}\text { Kawasan } \\
\text { Babagan }\end{array}$ & $\begin{array}{c}\text { Kawasan } \\
\text { Soditan }\end{array}$ & $\begin{array}{c}\text { Kawasan } \\
\text { Sumber } \\
\text { Girang }\end{array}$ \\
\hline 1. & Kelangkaan & 3 & 3 & 3 & 1 \\
\hline 2. & Estetika & 3 & 3 & 3 & 2 \\
\hline 3. & Peranan sejarah & 3 & 2 & 3 & 1 \\
\hline 4. & Keistimewaan & 3 & 2 & 3 & 1 \\
\hline 5. & Kejamakan & 2 & 2 & 3 & 2 \\
\hline 6. & $\begin{array}{l}\text { Memperkuat kawasan } \\
\text { sekitar }\end{array}$ & 3 & 2 & $\mathbf{1 8}$ & $\mathbf{8}$ \\
\hline & $\quad$ JUMLAH & $\mathbf{1 7}$ & $\mathbf{1 4}$ & & 1 \\
\hline
\end{tabular}

Dari hasil penilaian kelayakan konservasi, maka elemen-elemen bangunan berdasarkan klasifikasi potensial tinggi (Nilai > 16) yaitu Kawasan Soditan dan Kawasan Karang Turi, potensial sedang (Nilai 11-15) yaitu Kawasan Babagan, dan potensial rendah (Nilai <10) yaitu Kawasan Sumber Girang. Penetapan zonasi konservasi Kawasan Pecinan Lasem yaitu (gambar 1):

- Zona 1 (kawasan prioritas penanganan) : 1) Kawasan Soditan dan 2) Kawasan Karang Turi

- Zona 2 : Kawasan Babagan

- Zona 3 : Kawasan Sumber Girang

Zona 1 merupakan zona prioritas penanganan yang memiliki score lebih dari 16. Zona 1 terdiri dari kawasan Soditan dan kawasan Karang Turi. Kawasan soditan memiliki score 17 sedangkan kawasan Karang Turi memiliki score 18. Kawasan Karang Turi memiliki score paling tinggi, dimana pada kawasan ini memiliki potensi untuk dikembangkan menjadi area perdagangan dan jasa karena dilalui oleh jalur transportasi Semarang-Surabaya. Selain itu, sebagian besar daerah tersebut digunakan untuk bangunan ruko dan rumah tinggal serta terdapat Kelenteng Poo An Bio yang menjadi pusat ibadah bagi masyarakat Cina yang tinggal di sekitar kawasan permukimannya. dengan adanya keunggulan dari segi kelangkaan, peranan sejarah, keistimewaan, estetika, kejamakan dan dapat memperkuat kawasan sekitar, zona 1 dapat menjadi primadona sebagai destinasi wisata utama di kawasan Pecinan Lasem. Oleh sebab itu perlu adanya upaya untuk menjaga, memelihara dan mempertahankan kelestarian zona 1 melalui konservasi kawasan. 


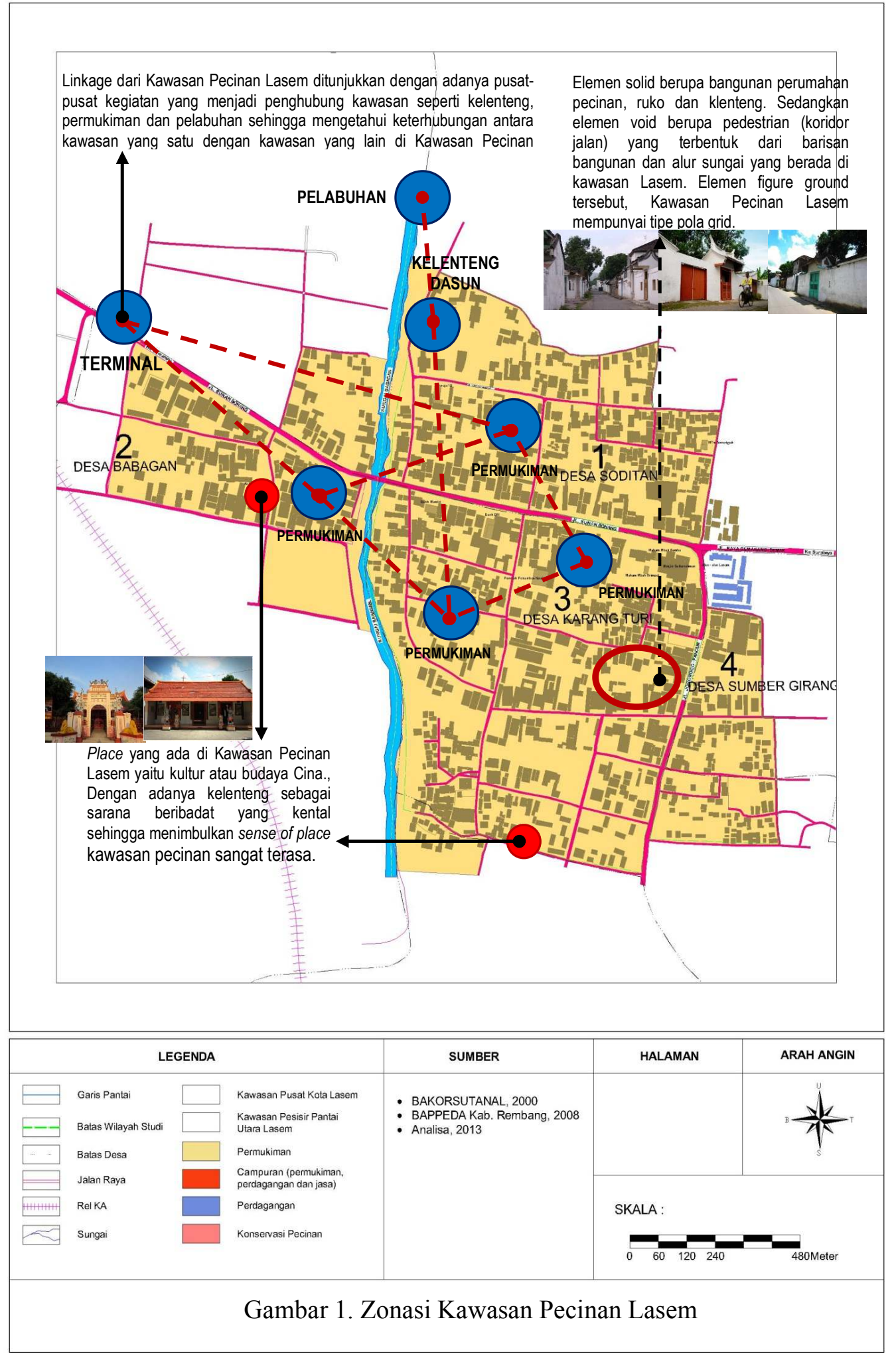

Zona 2 yaitu kawasan Babagan yang merupakan kawasan dengan potensial sedang. Kawasan Bagagan dikategorikan sebagai kawasan yang dengan kategori potensial sedang karena memiliki daerah permukiman Pecinan yang lebih sedikit daripada daerah Karangturi. Dilihat dari 
segi kelangkaan, terdapat Kelenteng Gie Yong Bio yang menjadi landmark di kawasan permukiman pecinan Babagan.Kawasan Sumber Girang tergolong sebagai kawasan zona 3, sebagai kawasan dengan tingkat potensial rendah (Nilai $<10$ ) dengan jumlah score 8 . Di kawasan Sumber Girang tidak terdapat banyak bangunan bersejarah dibandingan dengan kawasan Pecinan lainnya. Keistimewaan kawasan Sumber Girang yaitu lokasinya yang srategis yaitu dekat dengan pasar. Lokasi yang strategis dapat dimanfaatkan dibidang perdagangan dan jasa. Seluruh kawasan di Pecinan Lasem dapat dikembangkan sebagai kawasan konservasi karena memiliki potensi untuk dikembangkan dilihat dari kriteria kelayakan kawasan konservasi, khususnya pada zona 1 sebagai zona paling potensial. Zona 2 dan Zona 3 sebagai zona potensi sedang dan rendah juga harus dilakukan konservasi karena setiap zona memiliki keistimewaan masing-masing.

\section{KESIMPULAN}

Kawasan Pecinan Lasem layak untuk dikembangkan sebagai kawasan konservasi karena memiliki potensi yang dapat dikembangkan dilihat dari segi kriteria kelayakan kawasan konservasi yang meliputi kelangkaan, estetika, peranan sejarah, keistimewaan, kejamakan dan mampu memperkuat kawasan sekitar. Kelayakan kawasan konservasi Pecinan Lasem dibagi menjadi empat desa yaitu Desa Karangturi, Desa Babagan, Desa Soditan dan Desa Sumber Girang. Berdasarkan penilaian kelayakan terhadap empat kawasan Pecinan di Lasem, menunjukkan bahwa kawasan yang memiliki nilai paling tinggi (dengan nilai lebih besar dari 16) adalah kawasan Soditan dan Karang Turi yang berada di Zona 1. Zona 1 berpotensi sebagai destinasi wisata utama di kawasan Pecinan Lasem. Oleh sebab itu perlu adanya upaya untuk menjaga, memelihara dan mempertahankan kelestarian zona 1 melalui konservasi kawasan. Zona 2 yang merupakan kawasan dengan potensial sedang yaitu kawasan Babagan. Kawasan Bagagan dikategorikan sebagai kawasan yang dengan kategori potensial sedang karena memiliki daerah permukiman Pecinan yang lebih sedikit dibandingkan daerah Karangturi. Kawasan Sumber Girang tergolong sebagai kawasan zona 3, sebagai kawasan dengan tingkat potensial rendah dengan jumlah score 8, karena di kawasan Sumber Girang tidak terdapat banyak bangunan bersejarah dibandingan dengan kawasan Pecinan lainnya. Seluruh kawasan di Pecinan Lasem dapat dikembangkan sebagai kawasan konservasi karena memiliki potensi untuk dikembangkan dilihat dari kriteria kelayakan kawasan konservasi, khususnya pada zona 1 sebagai zona paling potensial. Zona 2 dan zona 3 sebagai zona potensi sedang dan rendah juga harus dilakukan konservasi karena setiap zona memiliki keistimewaan masing-masing. Untuk meningkatkan potensi dari setiap zona maka perlu dilakukan upaya pelestarian kawasan melalui konservasi kawasan, sehingga kawasan tetap terjaga dan terpelihara sebagai cagar budaya bersejarah.

\section{Rekomendasi}

1. Diharapkan penelitian selanjutnya dapat memberikan arahan konservasi yang tepat di kawasan Pecinan Lasem

2. Penelitian selanjutnya dapat meneliti mengenai manajemen pengembangan wisata di kawasan pecinan Lasem sehingga mampu menghidupkan kawasan Pecinan Lasem sebagai destinasi wisata sejarah dan budaya dan mampu meningkatkan tingkat perekonomian masyarakat.

\section{Ucapan Terima Kasih}

Terima kasih kepada Tutut Gustama, Ari Sutanto, L.Adi Widiarso, Desi Arianti dan Nur Aini yang membantu dalam penyusunan tulisan. 


\section{REFERENSI}

Adishakti. (2013). Modul 2 Prinsip, Strategi, dan Instrumen Penataan-Pelestarian Kota Pusaka. Badan Pelestarian Pusaka Indonesia. Jakarta.

Atabik, Ahmad. (2016). Harmonisasi Kerukunan Antar Etnis Dan Penganut Agama Di Lasem. Jurnal Ilmu Aqidah dan Studi Keagamaan, Volume 4 (Nomor 1), hal 36-49.

Budihardjo, Eko. (1985). Menuju Arsitektur Indonesia. Bandung: Penerbit PT Alumni.

Catanese, Anthony J dan James C. Snyder. (1989). Perencanaan Kota. Jakarta: Erlangga.

Darmawan, D. dan Hetyorini. Yin Yang, Chi Dan Wu Xing Pada Arsitektur Kelenteng Studi Kasus Kelenteng Sebelum Abad 19 Di Lasem, Rembang dan Semarang. Jurnal ilmiah UNTAG Semarang, hal 115-128.

Fajar A.H., 2005, Studi Identifikasi dan Penentuan Kawasan Pecinan Lasem, Tugas Akhir, PWK, UNDIP: Semarang.

Fauzy, B., Antariksa dan Salura, P.(2011). Memahami Relasi Konsep Fungsi, Bentuk Dan Makna Arsitektur Rumah Tinggal Masyarakat Kota Pesisir Utara Di Kawasan Jawa Timur (Kasus Studi Rumah Tinggal di Kampung Karangturi dan Kampung Sumber Girang, Lasem) . Dimensi, Vol. 38, Journal of Architecture and Built Environment (No. 2), hal 7988.

Gracea, Diana dan Dewi, S. Rima. (2014). Pelestarian Kawasan Pecinan Kembang Jepun Melalui Pendekatan Pola Public Private Partnership (PPP). Jurnal Teknik Pomits Volume 3, No.2, hal 92-97.

Hadinoto dan Samuel Hartono. (2006). "Lasem Kota Kuno di Pantai Utara Jawa Yang Bernuansa China”. Prosiding Seminar Nasional Pemahaman Sejarah Arsitektur Indonesia X, Arsitektur Pecinan Di Indonesia, Semarang, Jurusan Arsitektur Unika Sugijapranata.

Hasanah, Hasyim. (2014). Perayaan Imlek Etnis Tionghoa: Menakar Implikasi Psiko-Sosiologis Perayaan Imlek bagi Komunitas Muslim di Lasem Rembang. Jurnal Penelitian, Volume 8, No. 1, hal 1-22.

Markus, Zahnd. (1999) Perancangan Kota Secara Terpadu. Yogyakarta: Kanisius

Nasution.Megya. F.H dan Widya, Dharma. (2014). Pelestarian Kawasan Tanjung Pura sebagai Aset Wisata di Kabupaten Langkat. Jurnal Ruas, Volume 12, No.2, hal 20-31.

Trancik, Roger. (1986). Finding Lost Space: Theories of Urban Design. New York: Van Nostrand Reinhold Company.

Undang-Undang (UU) Nomor 5 Tahun 1992 tentang Benda Cagar Budaya. Pada Pasal 1 (1) disebutkan, benda cagar budaya.

Undang -Undang (UU) No. 11 tahun 2010 tentang Cagar Budaya. 